\title{
Evaluation of pig welfare in lairage and process hygiene in a single abattoir
}

\author{
Ivan Nastasijevic ${ }^{*}$, Brankica Lakicevic ${ }^{l}$, Mladen Raseta ${ }^{1}$, Vesna Djordjevic ${ }^{1}$, Vesna Jankovic ${ }^{l}$, \\ Boris Mrdovic ${ }^{1}$, Ivana Brankovic-Lazic ${ }^{1}$
}

A b s tra c t: Food safety is indirectly affected by the welfare of food animals, due to close links between animal welfare, animal health and food borne diseases. Stress factors and poor welfare can lead to increased susceptibility to disease among animals and may intensify the fecal shedding of food borne pathogens, e.g. Salmonella, Campylobacter, Yersinia, and human pathogenic STEC in the pre-slaughter phase: on-farm, in transport and in lairage. This study evaluated two aspects: a) assessment of pig welfare in abattoir lairage founded on animal-based categories, and b) the relationship between pig welfare and microbial process hygiene at slaughter. The results revealed that the animal-based category 'manure on the body' assessed in abattoir lairage corresponded with microbial process hygiene at slaughter.

Keywords: abattoir lairage, pig welfare, slaughter, process hygiene.

\section{Introduction}

Animal welfare is considered an important factor of an overall 'food quality' concept. Recently, there has been growing awareness and interest by the major stakeholders, e.g. industry, scientific community and consumers, in how animal welfare could also significantly impact food safety $(E F S A, 2012)$. The safety of the food chain is indirectly affected by welfare of animals farmed for food production, due to the close links between animal welfare, animal health and food borne diseases. Namely, the gastrointestinal tract of farm animals can be colonized by enteric, food borne pathogens, e.g. Salmonella, Campylobacter, human pathogenic Shiga toxin-producing E. coli (STEC), and Yersinia, and their subsequent dissemination into the human food chain is a major public health and economic concern for the food (meat) industries (Rostagno, 2009). Stress factors and poor welfare can lead to increased susceptibility to disease among animals and can intensify fecal shedding of food borne pathogens in the pre-slaughter phase: on-farm, in transport/livestock markets and in abattoir lairage (Buncic et al., 2013). Increased fecal shedding subsequently can increase the pre-slaughter cross-contamination of animals' skin with soil and fecal material during the transport and lay-over in lairage via contacts: animal-litter-animal, animal-floor-animal and animal-animal. In a study carried out by Berends et al. (1997), it was reported that the initial source of pig carcass contamination was the carrier pig itself $(70 \%)$, while the remaining $30 \%$ of the carcass contamination was related to the hygiene of slaughter and dressing.

Furthermore, poor hygienic practices during slaughter/dressing (e.g. evisceration) can additionally contribute to cross-contamination of pig carcasses and increase the probability for transfer of pathogens onto meat (Petruzzelli et al., 2016). These hazards can pose risks to consumers through meat consumption and provoke common food borne infections such as salmonellosis, yersiniosis, campylobacteriosis, or STEC infections.

Over recent years, several scientific opinions and guidelines on pig and cattle welfare at slaughter were developed. These documents were mainly focused on specific monitoring indicators to evaluate the effectiveness of stunning methods (EFSA, 2013a; 2013b). For instance, the current European Union legislation defines requirements for protection of animals at the time of killing, which is supported by the statement that "improving the protection of animals at the time of slaughter contributes to higher meat quality and indirectly has a positive

${ }^{1}$ Institute of Meat Hygiene and Technology, Kacanskog 13, 11000 Belgrade, Republic of Serbia.

*Corresponding author: Ivan Nastasijevic, ivan.nastasijevic@inmes.rs 
impact on occupational safety in slaughterhouses" (EC, 2009). The US legislation does not define regulatory requirement for a written systematic approach to humane handling, but provides a guideline with current thinking on the systematic approach to humane handling of livestock (USDA FSIS, 2013). With a systematic approach, establishments should focus on treating livestock in such a manner as to minimize excitement, discomfort, and accidental injury the entire time they hold livestock in connection with slaughter. Therefore, an establishment may choose to develop and implement a written animal handling program that effectively addresses the most important aspects of animal welfare. Evidently, although official guidelines in the EU and US on specific, pre-slaughter animal welfare indicators exist, they do not necessarily reflect specific welfare issues associated with abattoir lairage. Animal welfare implications for microbial process hygiene at slaughter/dressing are not considered in available literature.

Increased fecal shedding of food borne pathogens by animals intended for slaughter, due to higher levels of stress, as well as poor maintenance of abattoir lairage, e.g. slick floors (causing animals to slip and fall), poorly designed holding pens (insufficient space allowance) associated with management of lay-over time in lairage, inadequate environmental conditions (high or low temperature, high humidity, poor ventilation) could subsequently introduce higher levels of microbial load (including pathogens) to the slaughter line. This could affect the process hygiene at slaughter/dressing and increase the public health risk for consumers (Grandin, 1996) due to increased exposure to foodborne pathogens. Therefore, this study aimed to cover two aspects: a) assessment of pig welfare in abattoir lairage based on specific animal-based categories, and b) impact of pig welfare in abattoir lairage on microbial process hygiene at slaughter.

\section{Materials and methods}

\section{Company's profile}

The study was conducted in one meat processing company. The company had two separated slaughter lines (pig and cattle) with registered capacity of $240 \mathrm{pigs} / \mathrm{h}$ and $30 \mathrm{cattle} / \mathrm{h}$. The total space of lairage where pigs were kept prior to slaughter was composed of four holding pens (HP) and occupied in total: $342 \mathrm{~m}^{2}$ (HP1: $99 \mathrm{~m}^{2}$; HP2: $85 \mathrm{~m}^{2}$; HP3: $59 \mathrm{~m}^{2}$ and HP4: $99 \mathrm{~m}^{2}$ ).

\section{Pre-slaughter phase}

The company had two lairage units, one for pigs and another for cattle. Each lairage unit had its own unloading ramp. In this study, we evaluated lairage and farm/transport factors that could contribute to pig welfare prior to slaughter (Table 1).

\section{Lairage}

Hygienic-technical conditions. A team of three assessors evaluated the empty lairage in order to assess the position of premises versus the loading ramp and the corridor leading to the slaughter line, as well as to assess the general hygienic-technical conditions of holding pens.

Environmental conditions. The assessors measured: the level of lairage illumination, using the light intensity measuring instrument, a pocket-sized Lux meter (Testo 540, Germany); the ventilation, using an anemometer for quick and precise measurements of air flow speed, direction and volumetric flow rate (Testo 417, Germany), and; the ambient temperature, using a digital thermometer (Testo 905i, Germany). The ambient temperature was recorded once per week in the morning hours (between 6-7 am), corresponding with the start of operations in the abattoir, during February, March and April; this included the temperature measurements during the three scheduled visits to the meat company. Overall, 12 measurements of the ambient temperature were conducted during the study and the average monthly temperature was calculated for each of those three months.

Pre-slaughter sampling. A total of 3286 pigs were monitored over three scheduled visits in February (visit 1), March (visit 2) and April (visit 3), through deliveries to the abattoir in 13 consignments. The variables that were observed or measured are presented in Table 1. Delivery time, breed/ age, lay-over time in lairage, weight of pigs and space allowance were recorded and measured on the day of arrival by the lairage supervisor appointed by company's general manager, while other data (farm of origin, farm location, housing system), including animal identification and health status report issued by the official veterinarian at the farm of origin, were collected by assessors from the company's lairage reception recordkeeping during each of three scheduled visits.

Assessment of animal-based categories. Criteria intended for assessment of animal welfare in abattoir lairage are scarce in available literature. Therefore, the protocol recommended by the European Food Safety Authority (EFSA) intended for assessment 
Table 1. The variables assessed or measured in lairage related to abattoir premises, farms and traceability information

\begin{tabular}{|c|c|}
\hline \multirow{4}{*}{ Hygienic-technical conditions } & general hygienic-technical conditions of holding pens \\
\hline & position of lairage \\
\hline & loading ramp \\
\hline & corridor to slaughter line \\
\hline \multirow{3}{*}{ Environmental conditions } & lairage illumination \\
\hline & ventilation (air flow speed, direction, volumetric flow rate) \\
\hline & ambient temperature \\
\hline \multirow{8}{*}{ Pre-slaughter sampling } & delivery time \\
\hline & farm of origin \\
\hline & farm location \\
\hline & housing system \\
\hline & breed/age \\
\hline & weight of pigs \\
\hline & lay-over time \\
\hline & space allowance \\
\hline
\end{tabular}

of on-farm pig welfare (EFSA, 2012) was adapted in this study and used in the abattoir lairage and at the slaughter line to evaluate the factors that could contribute to pigs' welfare scores (Table 2). This approach is based on a group level assessment of animal-based categories, e.g. the factors that could contribute to pigs' welfare scores, in the lairage (ante-mortem) and at the slaughter line (post-mortem). In this study, the assessment protocol was applied in two stages: 1) assessment of welfare-related factors of pigs in the abattoir lairage (pre-slaughter), and 2) assessment of internal organs and carcasses at slaughter line (post-slaughter). The EFSA protocol uses the presence/absence of some of the animal-based categories (Table 2) and also uses given scores based on the availability of preventive measures.

Delphi method (scoring). The scoring of welfare of the fattening pigs in abattoir lairage was conducted using the Delphi method (Yousuf, 2007). Anumerical scoring system ranging from 0 (impossible to prevent hazard through short-term management) to 5 (full prevention possibility, the hazard can be prevented/eliminated almost instantly, on-the-spot) was used. Three experienced assessors participated in this survey; each assessor had more than seven years of professional experience working within the meat industry extension program. For each hazard in Table 2, the assessor visually observed the pigs in the abattoir lairage. The assessment was carried out in the abattoir lairage, and afterwards, the three assessors compared their scores while still on the abattoir premises. Mean values were calculated from the three assessor scores for each animal-based category. The highest score (5) corresponded to a 'management definition' as follows: a) management is anything that the responsible persons (be it animal owner or stockperson) can easily do themselves (e.g. moving barriers/gates) almost instantly, on-the-spot, but should exclude major activities, such as new buildings or replacing structural features of existing stables; b) management encompasses changes that can be made in a short term (to be implemented and consequences seen within a short period, but excluding long term management plans); c) management includes changes within the long term, without consideration of potential financial constraints (i.e. assuming that the manager can always take decision to change, if wanted). The lowest score ( 0 ) corresponded to the lowest management potential, e.g. construction-related housing, which also requires significant financial input and is time consuming.

In this study (Table 3), we also used the terminology 'space allowance' (FAWC, 2013) which denotes the space per animal $\left(\mathrm{m}^{2} /\right.$ head $)$ or 'capacity' (the maximum number of animals in a specific holding pen). 
Table 2. Summary of animal-based categories for fattening pigs (adapted from EFSA, 2012)

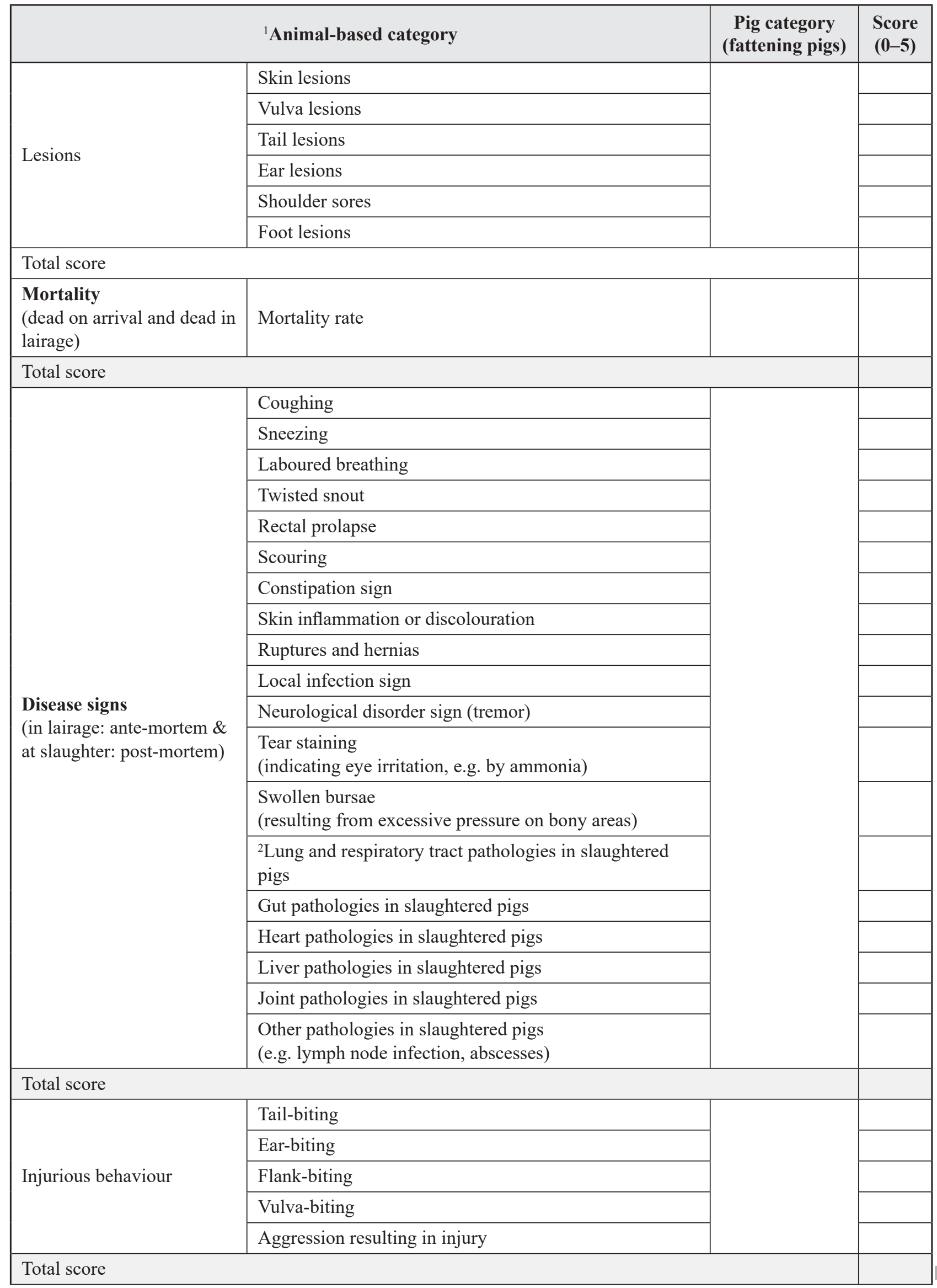




\begin{tabular}{|c|c|c|c|}
\hline & ${ }^{1}$ Animal-based category & $\begin{array}{l}\text { Pig category } \\
\text { (fattening pigs) }\end{array}$ & $\begin{array}{l}\text { Score } \\
(0-5)\end{array}$ \\
\hline \multirow{8}{*}{ Other behaviours } & $\begin{array}{l}\text { Persistent investigatory behaviour } \\
\text { (directed at pen-mates or pen-fittings) }\end{array}$ & & \\
\hline & $\begin{array}{l}\text { Exploratory behaviour } \\
\text { (involving diverse behavioural elements, e.g. directed } \\
\text { towards manipulable materials, not pen mates) }\end{array}$ & & \\
\hline & $\begin{array}{l}\text { Activity level } \\
\text { (increased in specific circumstances as predictor of } \\
\text { tail-biting) }\end{array}$ & & \\
\hline & Mounting behavior score & & \\
\hline & Play behaviour score & & \\
\hline & $\begin{array}{l}\text { Social isolation } \\
\text { (self-separation from the group as indicator of illness or } \\
\text { pain) }\end{array}$ & & \\
\hline & $\begin{array}{l}\text { Feeding and drinking behaviour - abnormal or presence } \\
\text { or absence - (from automated records) }\end{array}$ & & \\
\hline & Qualitative behavior assessment score & & \\
\hline \multicolumn{4}{|l|}{ Total score } \\
\hline \multirow{5}{*}{ Thermoregulation } & Panting & & \\
\hline & Huddling and shivering & & \\
\hline & Body temperature & & \\
\hline & $\begin{array}{l}\text { Lying location } \\
\text { (lying in dunging or other inappropriate area due to } \\
\text { spatial or thermal inadequacy) }\end{array}$ & & \\
\hline & $\begin{array}{l}\text { Lying posture } \\
\text { (sterna lying due to spatial or thermal inadequacy) }\end{array}$ & & \\
\hline \multicolumn{4}{|l|}{ Total score } \\
\hline Mutilations & Tail intact or docked & & \\
\hline \multicolumn{4}{|l|}{ Total score } \\
\hline \multirow{7}{*}{ Other measures } & $\begin{array}{l}\text { Approach to humans score } \\
\text { (fear of humans or positive reaction to humans) }\end{array}$ & & \\
\hline & Manure on the body score & & \\
\hline & $\begin{array}{l}{ }^{3} \text { Acute phase proteins } \\
\text { (at present only pigMAP in blood or meat juice is } \\
\text { practicable) }\end{array}$ & & \\
\hline & Locomotion score & & \\
\hline & Slipping and falling & & \\
\hline & $\begin{array}{l}\text { Body condition score } \\
\text { (under nutrition or sickness or incorrect feeding leading } \\
\text { to a low score - bad welfare conditions) }\end{array}$ & & \\
\hline & $\begin{array}{l}\text { Tail posture } \\
\text { (as predictor of tail-biting or indicator of disease) }\end{array}$ & & \\
\hline
\end{tabular}




\begin{tabular}{|c|c|c|c|}
\hline & ${ }^{1}$ Animal-based category & $\begin{array}{l}\text { Pig category } \\
\text { (fattening pigs) }\end{array}$ & $\begin{array}{l}\text { Score } \\
(0-5)\end{array}$ \\
\hline \multicolumn{3}{|l|}{ Total score } & \\
\hline \multirow{6}{*}{$\begin{array}{l}\text { Insufficient space } \\
\text { or } \\
\text { too high stocking density }\end{array}$} & Rest and sleep disruption & & \\
\hline & Stress and lesions & & \\
\hline & Behavioural restriction & & \\
\hline & $\begin{array}{l}\text { Damaging behavior from pen mates } \\
\text { (biting, massaging, belly nosing, etc.). }\end{array}$ & & \\
\hline & Pain due to leg problems. & & \\
\hline & Being tail bitten. & & \\
\hline \multicolumn{4}{|l|}{ Total score } \\
\hline \multirow{3}{*}{ Rest and sleep disruption } & $\begin{array}{l}\text { No comfortable lying place, insufficient solid floor or no } \\
\text { bedding material like straw }\end{array}$ & & \\
\hline & $\begin{array}{l}\text { Inappropriate pen design: } \\
\text { Inadequate separation of dunging and lying area and } \\
\text { other inadequacy (feeders, drinkers, etc.) }\end{array}$ & & \\
\hline & Inappropriate pen lay out: open sides to pens & & \\
\hline \multicolumn{3}{|l|}{ Total score } & \\
\hline \multicolumn{2}{|l|}{ TOTAL } & & \\
\hline
\end{tabular}

Legend: ${ }^{1}$ Animal-based category: "a response of an animal or an effect on an animal" (EFSA, 2012); ${ }^{2}$ Post-mortem animal-based categories; ${ }^{3}$ Acute phase proteins in blood or meat juice were not considered in this study

Human approach test. The human approach test took place in abattoir lairage. A total of 120 pigs were observed (one batch included 10 pigs from each of four holding pens; in total, 40 pigs per visit), over the three visits. The test was carried out in the four holding pens where fattening pigs intended for slaughter were placed. Assessors wore jumpsuits and boots which had been freshly cleaned before every test. One assessor approached carefully and stood still in front of each of the four holding pens, for one minute. The pigs could generally use their snouts to make contact with the boots or the legs of the assessor. During that time, the other two assessors recorded which pigs made physical contact with the person and noted the latency of the pigs (LC) to touch the first assessor. Pigs which did not contact the assessor in the test time of $60 \mathrm{~s}$ were scored as having the maximum latency time (latency to the first escape attempt/LEA $=60 \mathrm{~s}$ ). Each pig had an ear tag with an individual number and the latency was recorded for each individual pig.

Physiological measurements. The rectal temperatures of selected fattening pigs were recorded. Six pigs that approached the assessor in the human approach test and had no visible signs of disease were randomly selected from each of the four holding pens.
The selected pigs were restrained in the lairage pen and rectal temperature was measured with the digital thermometer (Nasco C28178N, US); the selected pigs did not necessarily originate from the same farm.

\section{Post-slaughter phase}

In the post-slaughter phase, meat $\mathrm{pH} /$ temperature of carcasses was measured; process hygiene levels at slaughter were also determined.

After slaughter (60 min post-slaughter), initial $\mathrm{pH}$ and temperature ( $\mathrm{pH} /$ Temperature meter Testo 205, Germany) were measured in 15 selected pig carcasses on each of three visits, to reveal the potential distress of pigs prior to slaughter; $\mathrm{pH}$ and temperature measurements were taken at the middle region of the LTL muscle (muscularis longissimuss thoracis et lumborum). In total, $\mathrm{pH}$ and temperature was measured in 45 selected pig carcasses.

Process hygiene sampling. The sampling was carried out in the abattoir lairage and on the slaughter line. In the lairage, six samples were taken in a systematic way (i.e. three samples from the floor of the holding pen and three samples from the corners between concrete walls of the holding pen). The samples were taken with sponge covering $1000 \mathrm{~cm}^{2}$ 
for each swabbing. The sponge samples were wetted with $10 \mathrm{~mL}$ of maximum recovery diluent (MRD, Oxoid UK), packed in a stomacher bags (19 x 30 $\mathrm{cm}$, Nasco, Whirl-pak, USA) and transported within 3-4 $\mathrm{h}$ in a cool bin at $<4^{\circ} \mathrm{C}$ to laboratory and processed on a same day; only the presence/absence of Salmonella spp. was examined in these lairage environmental samples (ISO 6579:2002).

Five pigs were individually identified in the abattoir lairage (i.e. black color mark on the back) for subsequent sampling on the slaughter line. Sponge swab samples were taken from four sites on the carcasses of the five pigs (rump, back, flank and jowl) (ISO 17604:2015) using a $100 \mathrm{~cm}^{2}$ sterile template and one sponge per site, at four locations along the slaughter line: lairage/after stunning; after scalding/ singeing/polishing (pre-evisceration); after evisceration; and after the final wash. Swabs were packed in a stomacher bags $(19 \times 30 \mathrm{~cm}$, Nasco, Whirl-pak, USA), transported within 3-4 h in a cool bin at $<4^{\circ} \mathrm{C}$ to the laboratory, and processed (see below) on the same day.

For each sponge swab sample of pig carcasses, the levels of process hygiene indicators, e.g. Total Viable Counts (TVC) (ISO 4833:2003), Enterobacteriaceae (EC) (ISO 21528-2:2004), generic E. coli (GEC) (ISO 16649-1:2001) and Coliforms (ISO 4832:2006) were determined to verify the process hygiene level at slaughter/dressing. Further, the presence/absence of Salmonella spp. was also determined in these pig carcass swab samples (ISO 6579:2002).

The four counts for TVC/EC/GEC/Coliforms per carcass were first converted into $\log \mathrm{CFU} / \mathrm{cm}^{2}$, those log values for each of the four sampling sites/ carcass were summed, and then the mean log CFU/ $\mathrm{cm}^{2}$ per carcass was calculated. As the EU legislation $(E C, 2005)$ set limits for daily log mean counts, this was calculated from the five sampled carcasses. However, it has to be taken into account that EU process hygiene assessment legislation relates only to the final carcasses, and not to carcasses at earlier stages of the slaughter line that were sampled in this study.

Statistical analysis. Statistical analysis of the results was conducted using the software GraphPad Prism version 5.00 for Windows (GraphPad Software, San Diego, California USA). The group of pigs examined on one visit was considered as the experimental unit. The parameters obtained at ante-mortem and post-mortem assessment (animal-based measure categories) were described by descriptive statistics (mean, standard deviation, range). Relationships between ante-mortem animal-based categories' scores, obtained by the Delphi scoring method and microbiological status of carcasses (TVC, EC, GEC, Coliforms) were determined by Fisher's exact test. Values of $\mathrm{p}<0.05$ were considered significant.

\section{Results and discussion}

The hygienic-technical and environmental conditions in the abattoir lairage, status of pigs prior to slaughter, as well as observation of animal-based categories, human approach test, $\mathrm{pH}$ and temperature of dressed carcasses and microbiological process hygiene at slaughter/dressing were addressed in this study.

\section{Observation in pre-slaughter phase}

\section{Hygienic-technical conditions in lairage}

The unloading ramp from truck to lairage was sloped at a $15^{\circ}$ uphill angle. The isolation room for pigs potentially unfit for slaughter and requiring additional veterinary examination was in accordance with regulations.

Loading facilities and holding pens for pigs were made of a solid concrete non-slipping floor; flooring surfaces were uniform in appearance and mostly free from puddles and excessive cracks. Slats in holding pens were positioned in the proper direction so that pigs could walk across the slats instead of parallel with them. No intensive light and/or water reflections were observed under the slats, which facilitates the movement of animals. Drains were properly located outside the areas where animals walk. Watering (round pipe posts) and feeding facilities were installed so as to allow easy and smooth access by animals. However, some surfaces which came into contact with animals, including sharp corners, were not smooth and rounded. The majority of holding pen gates were equipped with tie-backs to prevent them from swinging out into the alley, except one. On the other hand, guillotine gates were adequate, counter-weighted and padded on the bottom. No differences regarding hygienic-technical conditions in the lairage across our three visits were observed.

\section{Environmental conditions in lairage}

The lairage was dimly illuminated, which supported the tendency of animals to move more easily in comparison to brightly illuminated space, as recommended by Grandin (1996). The lairage was well-ventilated and also had equipment available for water spraying and cooling of pigs. However, the steel gate strike posts did not have rubber stops 
to reduce noise and were operated manually. Major differences in ambient temperature (Table 3 ) were measured in our three separate visits, but other environmental conditions in the lairage were similar across our three visits.

\section{Status of pigs prior to slaughter}

Deliveries of fattening pigs intended for slaughter usually occurred in the early afternoon hours (between $1 \mathrm{pm}$ and $6 \mathrm{pm}$ ). The pigs originated mostly from farms with controlled housing systems (e.g. biosecurity and herd health surveillance programs), belonging to the company's own supply chain $(>90 \%)$. Most of the farms were located in the region with an average transportation time to the abattoir of 7-8 h, while only a few farms were located in relative proximity, with an average transportation time of 3-4 h. Fattening pigs were of Landrace breed $(80 \%)$, as well as Yorkshire or Berkshire (20\%). The live weights of animals arriving in the abattoir lairage ranged from $95-110 \mathrm{~kg}$. All fattening pigs intended for slaughter were accompanied with a valid veterinary health certificate, issued by the local veterinary authority, stating the health status of each animal, including the traceability. Upon arrival in abattoir lairage, the pigs' access to feed was restricted for up to $12 \mathrm{~h}$ prior to slaughter in order to prevent diarrhea and possible cross-contamination of carcasses during slaughter (i.e. scalding, evisceration); drinking water was available at all times from an appropriate watering system-ound pipe posts.

\section{Observation of animal-based categories}

During our three visits to the abattoir, the space allowance ranged from $0.39-1.00 \mathrm{~m}^{2} / \mathrm{pig}$ (Table $3)$. These findings were not in line with recommendations for space allowance in abattoir lairage of $0.66 \mathrm{~m}^{2} / \mathrm{pig}$, as suggested by Weeks (2008), but were in accordance with the Royal Society for the Prevention of Cruelty to Animals 'Freedom Foods scheme' (RSPCA, 2014); this scheme applies the minimum total area for pigs $\left(\mathrm{m}^{2}\right.$ per animal) of 0.15 when $<100$ pigs, and 0.225 when $<101-250$ in a holding pen. In available literature, space allowances for groups of animals of a uniform weight (Spoolder et al., 2008; Weeks, 2000; Faucitano, 2010; FAWC, 2013, RSPCA, 2014) or space allowances during transport (Sutherland et al. 2010) are usually described. In this study, the live weight of pigs intended for slaughter ranged from $95-110 \mathrm{~kg}$ and this created some difficulty in specifying the area allowance when animals within one group were of relatively different weights. The management of space allowance can be effectively performed by the company itself, with the responsible person moving flexible barriers/gates and so adjusting the available space within the holding pen based on the dynamic of the incoming animals. However, space management will also require careful planning of the slaughter logistics which should include scheduling the truck deliveries to reduce waiting times for unloading, as well as lay-over in abattoir lairage prior to slaughter. Such adjustment could be a cost-effective approach to fulfilling animal welfare requirements, because it should not require expensive reconstruction/adaptation of the lairage and it can be implemented and/or performed in a short period of time.

The relatively long pre-slaughter lay-over times in abattoir lairage observed in this study $(>14 \mathrm{~h}$; Table 3) were not associated with fighting, aggressive behavior or excessive skin damage as reported in a study carried out in a Dutch abattoir (Geverink et al.,1996), as well as in other studies conducted in Spain (Guàrdia et al., 2009) and the UK (Weeks, 2008). On the other hand, this was in line with a study in which it was observed that most fighting and aggressive behavior among pigs in abattoir lairage occurs within the first 30-60 minutes, and it is usually not significantly increased with up to $18 \mathrm{~h}$ of lay-over time (Fraqueza et al., 1998). Guàrdia et al. (2010) carried out a study in Spain and also discussed high stocking density and lairage time related to increased risk of dark, firm, dry (DFD) meat, associated with pre-slaughter/on-farm fasting times longer than $22 \mathrm{~h}$; the results from their study revealed that lowering the stocking density from 0.37 to $0.50 \mathrm{~m}^{2}$ per $100 \mathrm{~kg}$ pig during transport would reduce the risk of DFD pork by $11 \%$, but no observations regarding the lay-over time in abattoir lairage and implications on process hygiene at slaughter were provided in that study. Also, Candiani et al. (2008) evaluated physiological and behavioral indicators to provide useful information on pig welfare on farm, but without taking into consideration the status of pigs in abattoir lairage. Nonetheless, it should always be taken into account that a longer lairage lay-over time allows for rest but sometimes may increase the risk of aggression and thereby excessive skin damage (Faucitano, 2010).

The five ante-mortem animal based-categories with the lowest scores, in increasing order, (Table 4) were 'thermoregulation', 'manure on the body', 'insufficient space', 'injurious behavior', and 'lesions'. Although data on animal based-categories for fattening pigs in abattoir lairage in the available literature are scarce, these findings are similar to observations reported by Gispert et al. (2000) and Spoolder et al. (2000), who observed that major concerns in 
Table 3. Pre-slaughter conditions in abattoir lairage (three visits; $n=3286$ )

\begin{tabular}{|c|c|c|c|c|}
\hline $\begin{array}{l}\text { Holding Pen } \\
\text { (HP) }\end{array}$ & $\begin{array}{c}\text { Space allowance } \\
\mathbf{m}^{2} / \text { pig } \\
\mathrm{X} \pm \text { SD, range }\end{array}$ & $\begin{array}{c}\text { Lairage } \\
\text { lay-over time } \\
X \pm \text { SD }\end{array}$ & $\begin{array}{c}{ }^{3} \text { Rectal temperature } \\
\left({ }^{\circ} \mathrm{C}\right) \\
\mathrm{X} \pm \mathrm{SD} \text {, range }\end{array}$ & $\begin{array}{c}\text { In-lairage ambient } \\
\text { temperature }\left({ }^{\circ} \mathrm{C}\right) \\
\mathrm{X} \pm \mathrm{SD} \text {, range }\end{array}$ \\
\hline \multicolumn{5}{|c|}{ Visit I } \\
\hline HP1 & $0.66 \pm 0.41,0.24-0.75$ & $>14 \mathrm{~h}(14.5 \pm 0.24)$ & $38.5 \pm 0.25,38.1-39.0$ & \multirow{4}{*}{$9 \pm 0.17,8.7-9.3$} \\
\hline HP2 & $0.70 \pm 0.56,0.27-0.81$ & $\begin{array}{c}>14 \mathrm{~h} \\
(14.8 \pm 0.35)\end{array}$ & $38.1 \pm 0.23,38.0-38.8$ & \\
\hline HP3 & $0.39 \pm 0.18,0.22-0.48$ & $\begin{array}{c}>14 \mathrm{~h} \\
(14.9 \pm 0.42)\end{array}$ & $38.3 \pm 0.21,38.1-38.9$ & \\
\hline HP4 & $0.49 \pm 0.37,0.29-0.57$ & $\begin{array}{c}>18 \mathrm{~h} \\
(18.6 \pm 0.51)\end{array}$ & $38.5 \pm 0.27,38.0-39.3$ & \\
\hline \multicolumn{5}{|c|}{ Visit II } \\
\hline HP1 & $0.58 \pm 0.23,0.23-0.71$ & $\begin{array}{c}>18 \mathrm{~h} \\
(18.9 \pm 0.18)\end{array}$ & $38.3 \pm 0.18,37.9-39.1$ & \multirow{5}{*}{$14 \pm 0.21,13.8-14.2$} \\
\hline${ }^{1} \mathrm{HP} 2$ & - & - & - & \\
\hline HP3 & $0.39 \pm 0.21,0.22-0.45$ & $\begin{array}{c}>16 \mathrm{~h} \\
(17.2 \pm 0.37)\end{array}$ & $38.2 \pm 0.22,38.0-38.8$ & \\
\hline $\mathrm{HP} 4 / 1$ & $0.44 \pm 0.32,0.33-0.58$ & $\begin{array}{c}>20 \mathrm{~h} \\
(20.4 \pm 0.28)\end{array}$ & $39.3 \pm 0.28,38.4-39.6$ & \\
\hline $\mathrm{HP} 4 / 2$ & $0.42 \pm 0.19,0.34-0.51$ & $\begin{array}{c}>19 \mathrm{~h} \\
(19.6 \pm 0.21)\end{array}$ & $38.1 \pm 0.23,38.0-38.7$ & \\
\hline \multicolumn{5}{|c|}{ Visit III } \\
\hline${ }^{2} \mathrm{HP} 1 / 1$ & $0.40 \pm 0.31,0.26-0.52$ & $\begin{array}{c}>19 \mathrm{~h} \\
(19.2 \pm 0.29)\end{array}$ & $37.8 \pm 0.35,37.7-38.8$ & \multirow{6}{*}{$12 \pm 0.19,11.9-12.1$} \\
\hline $\mathrm{HP} 1 / 2$ & $1.00 \pm 0.37,0.29-0.1,4$ & $\begin{array}{c}>14 \mathrm{~h} \\
(14.3 \pm 0.31)\end{array}$ & $38.2 \pm 0.23,38.0-38.9$ & \\
\hline${ }^{1} \mathrm{HP} 2$ & - & - & - & \\
\hline HP3 & $0.44 \pm 0.23,0.31-0.56$ & $\begin{array}{c}>14 \mathrm{~h} \\
(14.8 \pm 0.36)\end{array}$ & $38.3 \pm 0.27,38.1-39.2$ & \\
\hline $\mathrm{HP} 4 / 1$ & $0.46 \pm 0.34,0.25-0.57$ & $\begin{array}{c}>16 \mathrm{~h} \\
(16.4 \pm 0.17) \\
\end{array}$ & $38.1 \pm 0.20,37.9-38.8$ & \\
\hline $\mathrm{HP} 4 / 2$ & $0.83 \pm 0.42,0.34-0.94$ & $\begin{array}{c}>14 \mathrm{~h} \\
(14.1 \pm 0.19)\end{array}$ & $39.0 \pm 0.29,38.2-39.5$ & \\
\hline
\end{tabular}

Legend: HP1: 99m²(HP1/1: 49m², HP1/2: 50m²); HP2:85m²; HP3:59m², HP4:99m² (HP4/1: 49m², HP4/2: 50m²)

${ }^{1}$ The holding pen no. 2 (HP2) was not used in third visit, since no fattening pigs were kept in this pen during this time;

${ }^{2} \mathrm{HP} 1 / 1, \mathrm{HP} 1 / 2, \mathrm{HP} 4 / 1$ and HP4/2 denotes holding pens where there is a possibility to move/change the position of internal barrier/gate to adjust the space allowance within the respective holding pen; ${ }^{3}$ Normal temperature range for pigs: $38.7-39.8^{\circ} \mathrm{C}$

fattening pigs in abattoir lairage were associated with the skin damage and injurious behavior. The findings regarding post-mortem animal-based categories revealed that the three categories with the lowest scores (Table 4), which could be deserving of being regularly monitored on the slaughter line, were 'gut pathologies', 'lung and respiratory tract pathologies' and 'liver pathologies'. Such findings could be very helpful to identify animal health and welfare issues related to zoo-technical (e.g. ventilation) or biosecurity (e.g. feed disposal, manure management, vaccination) conditions at the farm of origin, as well as to provide the valuable feedback to farmers (Horchner and Pointon, 2011). The correlation analyses between five ante-mortem animal-based categories and microbiological status of carcasses showed that 'manure on the body' was associated with all defined process hygiene indicators $(p<0.05)$, e.g. TVC, EC, GEC and Coliforms, while none of these five animal based-categories correlated with post-mortem findings (i.e. the visually observed pathologies observed in internal organs). 
Table 4. Scores for hazard-pig category combinations for fattening pigs in abattoir lairage

\begin{tabular}{|c|c|c|c|c|}
\hline \multirow[t]{2}{*}{ No. } & \multirow[t]{2}{*}{ Animal-based measure category } & \multicolumn{3}{|c|}{$\begin{array}{l}\text { Overall score }(\mathbf{0}-5) \\
\mathrm{X} \pm \mathrm{SD} \\
\end{array}$} \\
\hline & & Session I & Session II & Session III \\
\hline \multicolumn{5}{|c|}{ Ante-mortem $(n=3286)$} \\
\hline \multirow[b]{2}{*}{1} & \multirow[b]{2}{*}{ Lesions } & \multicolumn{3}{|c|}{$3.83 \pm 1.05$} \\
\hline & & $\begin{array}{l}\text { Session I } \\
3.80\end{array}$ & $\begin{array}{l}\text { Session II } \\
3.50\end{array}$ & $\begin{array}{l}\text { Session III } \\
\quad 4.20\end{array}$ \\
\hline \multirow[b]{2}{*}{2} & \multirow[b]{2}{*}{ Mortality } & \multicolumn{3}{|c|}{$5.00 \pm 0.00$} \\
\hline & & $\begin{array}{l}\text { Session I } \\
5.00\end{array}$ & $\begin{array}{l}\text { Session II } \\
5.00\end{array}$ & $\begin{array}{l}\text { Session III } \\
5.00\end{array}$ \\
\hline \multirow[b]{2}{*}{3} & \multirow{2}{*}{$\begin{array}{l}\text { Disease signs } \\
\text { (in lairage: ante-mortem \& at slaughter: post-mortem) }\end{array}$} & \multicolumn{3}{|c|}{$4.05 \pm 1.83$} \\
\hline & & $\begin{array}{l}\text { Session I } \\
3.90\end{array}$ & $\begin{array}{l}\text { Session II } \\
4.10\end{array}$ & $\begin{array}{l}\text { Session III } \\
\quad 4.15\end{array}$ \\
\hline \multirow[b]{2}{*}{4} & \multirow[b]{2}{*}{ Injurious behaviour } & \multicolumn{3}{|c|}{$3.80 \pm 1.67$} \\
\hline & & $\begin{array}{l}\text { Session I } \\
3.90 \\
\end{array}$ & $\begin{array}{l}\text { Session II } \\
3.4\end{array}$ & $\begin{array}{c}\text { Session III } \\
4.1\end{array}$ \\
\hline \multirow[b]{2}{*}{5} & \multirow{2}{*}{$\begin{array}{l}\text { Other behaviours } \\
\text { (persistent investigatory behavior, exploratory behavior, } \\
\text { mounting behavior, social isolation, feeding and drinking } \\
\text { behavior) }\end{array}$} & \multicolumn{3}{|c|}{$3.90 \pm 1.78$} \\
\hline & & $\begin{array}{l}\text { Session I } \\
\quad 4.10\end{array}$ & $\begin{array}{l}\text { Session II } \\
3.70\end{array}$ & $\begin{array}{l}\text { Session III } \\
\quad 3.90\end{array}$ \\
\hline \multirow[b]{2}{*}{6} & \multirow[b]{2}{*}{ Thermoregulation } & \multicolumn{3}{|c|}{$3.50 \pm 1.42$} \\
\hline & & $\begin{array}{l}\text { Session I } \\
3.2\end{array}$ & $\begin{array}{l}\text { Session II } \\
3.8\end{array}$ & $\begin{array}{l}\text { Session III } \\
3.5\end{array}$ \\
\hline \multirow[b]{2}{*}{7} & \multirow[b]{2}{*}{ Mutilations } & \multicolumn{3}{|c|}{$4.12 \pm 2.54$} \\
\hline & & $\begin{array}{l}\text { Session I } \\
3.9\end{array}$ & $\begin{array}{l}\text { Session II } \\
3.4 \\
\end{array}$ & $\begin{array}{l}\text { Session III } \\
4.2 \\
\end{array}$ \\
\hline \multirow[b]{2}{*}{8} & \multirow[b]{2}{*}{ Manure on the body } & \multicolumn{3}{|c|}{$3.65 \pm 1.91$} \\
\hline & & $\begin{array}{l}\text { Session I } \\
4.1\end{array}$ & $\begin{array}{l}\text { Session II } \\
3.3\end{array}$ & $\begin{array}{l}\text { Session III } \\
3.6\end{array}$ \\
\hline \multirow[b]{2}{*}{9} & & & $3.73 \pm 1.21$ & \\
\hline & Insufficient space & $\begin{array}{l}\text { Session I } \\
4.0\end{array}$ & $\begin{array}{l}\text { Session II } \\
3.4\end{array}$ & $\begin{array}{l}\text { Session III } \\
3.8\end{array}$ \\
\hline & & & $4,10 \pm 2.15$ & \\
\hline 10 & Rest and sleep disruption & $\begin{array}{c}\text { Session I } \\
4.1\end{array}$ & $\begin{array}{c}\text { Session II } \\
4.0\end{array}$ & $\begin{array}{c}\text { Session III } \\
4.2\end{array}$ \\
\hline & Post-mortem $(n=3$ & & & \\
\hline & & & $1.42 \pm 0.53$ & \\
\hline 1 & Lung and respiratory tract pathologies in slaughtered pigs & $\begin{array}{c}\text { Session I } \\
1.85 \\
\end{array}$ & $\begin{array}{c}\text { Session II } \\
0.85\end{array}$ & $\begin{array}{c}\text { Session III } \\
1.55\end{array}$ \\
\hline & & & $1.05 \pm 0.21$ & \\
\hline 2 & Gut pathologies in slaughtered pigs & $\begin{array}{c}\text { Session I } \\
1.25 \\
\end{array}$ & $\begin{array}{c}\text { Session II } \\
0.70\end{array}$ & $\begin{array}{c}\text { Session III } \\
1.20\end{array}$ \\
\hline & & & $3,27 \pm 1.15$ & \\
\hline 3 & Heart pathologies in slaughtered pigs & $\begin{array}{c}\text { Session I } \\
3.65\end{array}$ & $\begin{array}{c}\text { Session II } \\
2.80\end{array}$ & $\begin{array}{c}\text { Session III } \\
3.35\end{array}$ \\
\hline & & & $2.90 \pm 0.94$ & \\
\hline 4 & Liver pathologies in slaughtered pigs & $\begin{array}{c}\text { Session I } \\
3.25\end{array}$ & $\begin{array}{c}\text { Session II } \\
2.50\end{array}$ & $\begin{array}{c}\text { Session III } \\
2.95\end{array}$ \\
\hline & & & $4.05 \pm 0.15$ & \\
\hline 5 & Joint pathologies in slaughtered pigs & $\begin{array}{c}\text { Session I } \\
4.20\end{array}$ & $\begin{array}{c}\text { Session II } \\
3.85\end{array}$ & $\begin{array}{c}\text { Session III } \\
4.10\end{array}$ \\
\hline & & & $3.38 \pm 0.23$ & \\
\hline 6 & $\begin{array}{l}\text { Other pathologies in slaughtered pigs } \\
\text { (e.g. lymph node infection, abscesses) }\end{array}$ & $\begin{array}{c}\text { Session I } \\
3.90\end{array}$ & $\begin{array}{c}\text { Session II } \\
2.85\end{array}$ & $\begin{array}{c}\text { Session III } \\
3.40\end{array}$ \\
\hline
\end{tabular}




\section{Human approach test}

The test showed that, out of 120 pigs observed over the three visits, the response of animals was very good, so all pigs from each batch, and from each holding pen, wanted to have physical contact with the assessor. The latency of the pigs (LC) to touch the assessor was always less than $60 \mathrm{~s}$ (Table 5).

\section{pH and temperature of dressed carcasses (post-slaughter)}

$\mathrm{pH}$ values and temperatures of dressed carcasses, measured 60 min post-slaughter, ranged between batches/three visits from $\mathrm{pH} 5.81$ to 6.60 and $39.5-42.0^{\circ} \mathrm{C}$; after $12 \mathrm{~h}$, from $\mathrm{pH} 5.62$ to 5.83 and $3.0-3.9^{\circ} \mathrm{C}$, and; after $24 \mathrm{~h}$, from $\mathrm{pH} 5.60$ to 5.79 and $2.20-3.50^{\circ} \mathrm{C}$. These values are similar to those reported in a study carried out by Dokmanovic et al. (2014). In our study, recorded $\mathrm{pH} /$ temperature values of carcasses were in line with usual values for the post-slaughter period and did not indicate the animals had undergone excessive stress. A significant relationship between pre-slaughter stress and meat quality has been documented (Ferguson et al., 2001; del Campo et al., 2014). On the other hand, there is a lack of valid scientific data on stress-inducing factors in abattoir lairage. In a study conducted in Spain, Gispert et al. (2000) collected a random blood samples at exsanguination to determine cortisol, creatine phospho-kinase (CPK), lactate, and the halothane genotype; it was concluded that the most relevant stress indicators that may influence the carcass and meat quality in abattoir are associated with environmental aspects at pre-slaughter phase, e.g. high stocking density, long lay-over time in lairage and on-line skin damage.

\section{Microbiological process hygiene at slaughter/ dressing}

Microbiological process hygiene indicators monitored on pig carcasses (TVC, EC, GEC and Coliforms) differed on the three visits (Figure 1). In the three visits, the carcasses were sampled at two stages along the slaughter line (at stunning/before bleeding and after scalding/singeing/polishing).

Table 5. Human approach test carried out in abattoir lairage (three visits; $n=3286$ )

\begin{tabular}{|c|c|c|}
\hline $\begin{array}{c}\text { Holding Pen (HP) } \\
\text { (the batch - 10 pigs) }\end{array}$ & $\begin{array}{c}\text { 'LC } \\
\mathbf{X} \pm \text { SD, range }\end{array}$ & $\begin{array}{c}\text { 'LEA } \\
\mathbf{X} \pm \text { SD, range }\end{array}$ \\
\hline \multicolumn{3}{|c|}{ Visit I } \\
\hline HP1 & $35 \pm 0.42,10-52$ & $7 \pm 0.12,3-12$ \\
\hline HP2 & $24 \pm 0.53,7-46$ & $3 \pm 0.15,1-8$ \\
\hline HP3 & $49 \pm 0.17,17-51$ & $12 \pm 1.32,9-15$ \\
\hline HP4 & $53 \pm 0.34,32-57$ & $4 \pm 0.14,2-7$ \\
\hline & Visit II & $3 \pm 0.17,1-5$ \\
\hline HP1 & $23 \pm 0.37,13-41$ & - \\
\hline HP2 & - & $9 \pm 0.11,3-14$ \\
\hline HP3 & $44 \pm 0.27,27-51$ & $6 \pm 1.32,1-12$ \\
\hline HP4/1 & $48 \pm 0.31,31-54$ & $7 \pm 1.23,2-15$ \\
\hline HP4/2 & $52 \pm 0.23,38-58$ & \\
\hline & Visit III & $11 \pm 1.47,4-17$ \\
\hline HP1/1 & $25 \pm 0.19,12-34$ & $4 \pm 0.25,1-6$ \\
\hline HP1/2 & $37 \pm 0.27,23-46$ & - \\
\hline HP2 & - & $8 \pm 0.17,4-12$ \\
\hline HP3 & $42 \pm 0.31,35-49$ & $9 \pm 1.34,2-11$ \\
\hline HP4/1 & $32 \pm 0.24,19-43$ & $10 \pm 0.17,8-11$ \\
\hline HP4/2 & $30 \pm 0.41,17-40$ & \\
\hline
\end{tabular}

Legend: ${ }^{1} \mathrm{LC}$ - Latency of the pigs to touch the experimenter (expressed in seconds); ${ }^{2} \mathrm{LEA}$ - Latency to the first escape attempt (expressed in seconds; the maximum time $=60 \mathrm{~s}$ 


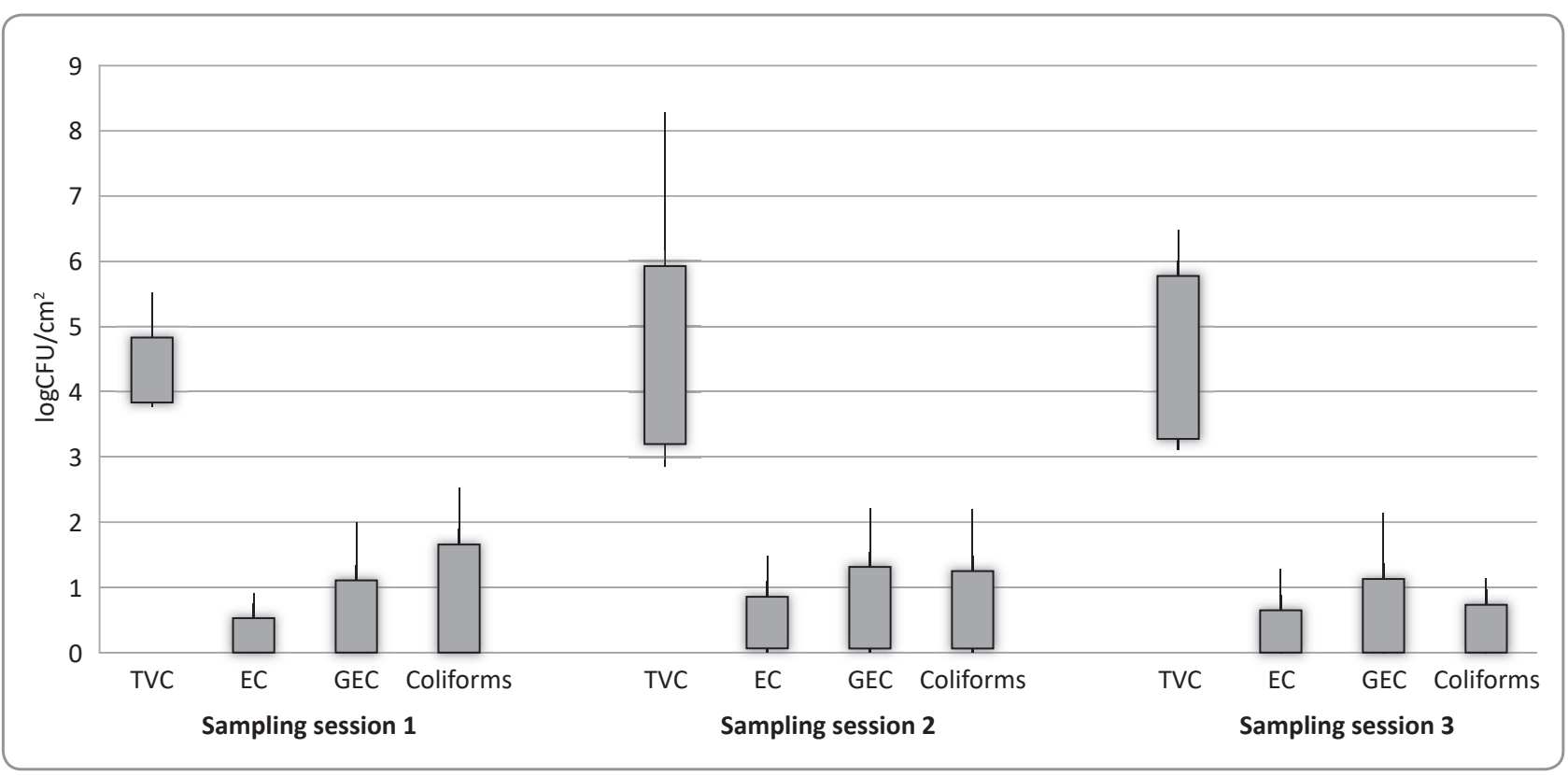

Legend: ${ }^{1}$ rump, back, belly, jowl

Figure 1. The levels of Total Viable Counts (TVC), Enterobacteriaceae (EC), generic E. coli (GEC) and Coliforms expressed in $\log \mathrm{CFU} / \mathrm{cm}^{2}$ at four sampling sites on pig carcasses ${ }^{1}$, obtained in three sampling sessions; sampling points along the slaughter line: stunning/before bleeding and scalding/singeing/polishing.

\section{Total viable counts (TVC)}

The mean log TVC levels, encompassing all levels determined at the four stages along the slaughter line, ranged between 3.80 and $5.51 \log \mathrm{CFU} / \mathrm{cm}^{2}$, 2.86 and $8.26 \log \mathrm{CFU} / \mathrm{cm}^{2}$ and between 3.12 and $6.46 \log \mathrm{CFU} / \mathrm{cm}^{2}$, respectively, on visits 1,2 , and 3. The highest TVC levels were measured after stunning/before bleeding $\left(8.20 \log \mathrm{CFU} / \mathrm{cm}^{2}\right)$, while the lowest TVC levels were obtained after the final wash/before chilling $\left(2.80 \log \mathrm{CFU} / \mathrm{cm}^{2}\right)$, which was in accordance with the EU legislation $(E C$, 2005). The TVC levels obtained after the final wash were slightly higher than reported in a Canadian study (Gill et al., 2000), but within the range reported in a study carried out in Swiss abattoirs (Zweifel et al. 2008). Furthermore, similar TVC levels were reported in a four-year monitoring study conducted in Italy (Petruzzelli et al., 2016).

\section{Enterobacteriaceae (EC), Generic E. coli (GEC) and Coliform counts}

The overall $E C$ levels observed in our three visits varied considerably, ranging from lower than the limit of detection to $1.48 \mathrm{log} \mathrm{CFU} / \mathrm{cm}^{2}$. The highest $E C$ levels were observed after stunning/before bleeding $\left(1.48 \log \mathrm{CFU} / \mathrm{cm}^{2}\right)$, while the lowest EC levels were obtained after scalding/singeing/polishing (lower than the limit of detection). The $E C$ levels after polishing were significantly lower than those reported by Zweifel et al. (2008) and Blagojevic et al. (2011).

The GEC levels varied appreciably during our three visits and ranged from lower than the limit of detection up to $2.22 \log \mathrm{CFU} / \mathrm{cm}^{2}$. The highest GEC levels were observed after stunning/before bleeding (2.22 log CFU/ $\mathrm{cm}^{2}$ ), while the lowest GEC levels were obtained after scalding/singeing/polishing (lower than the limit of detection). The results were similar to GEC levels reported by Gill et al. (2000) in a study in Canada, where 8 abattoirs with medium-to-high throughput were assessed for the level of process hygiene. Using the E. coli performance criteria (FSIS, 1996), the pig carcasses in the current study were categorised as within the acceptable range.

The Coliform levels determined during our three visits were similar to EC and GEC levels. Coliform levels ranged from lower than the limit of detection up to $2.53 \log \mathrm{CFU} / \mathrm{cm}^{2}$. Similarly, as with $E C$ and GEC levels, the highest Coliform levels were observed after stunning/before bleeding (2.53 $\log \mathrm{CFU} / \mathrm{cm}^{2}$ ), while the lowest values were obtained after scalding/singeing/polishing (lower than the limit of detection). Overall, these results indicated slightly lower level of hygiene than in a study carried out by Gill et al. (2000), where Coliform levels ranged from values lower than the limit of detection to $2.09 \log \mathrm{CFU} / \mathrm{cm}^{2}$. 
The levels of EC, GEC and Coliforms can be a useful indicator of abattoir-specific hygienic level (Zweifel et al. 2008). However, none of the aforementioned studies reflected on the interface between animal welfare in abattoir lairage and process hygiene at slaughter.

\section{Salmonella spp.}

No Salmonella was detected on pig carcasses or in environment surface samples taken from the abattoir lairage, which was in line with the EU criteria for this hazard $(\leq 5$ positive carcasses out of 50 , respectively; $E C, 2005)$. Another study conducted in the same region in Serbia also found low Salmonella occurrence on carcasses (Nastasijevic et al., 2016).

\section{Interface between animal-based categories and slaughter process hygiene}

Relationships between pig welfare variables (transportation time, animal-based categories, space allowance, lay-over time in lairage, ambient temperature), and microbial load values at slaughter were determined. The transportation time $(3-8 \mathrm{~h}$ from farm of origin to abattoir) observed in our three visits was not reflected in bacterial loads on carcasses (TVC, EC, GEC, Coliforms). Space allowance coupled with the lay-over time in lairage and ambient temperature tended to be related to process hygiene, as the lowest levels of hygiene indicators were observed in the first visit, where in-lairage space allowance was adequate, the lay-over time was shorter than in visits 2 and 3 , and the ambient temperature was also lower than in visits 2 and 3 (Table 3, Figure 1). However, the trends were non-significant. Nonetheless, after all these circumstances, we measured lower microbial loads on carcasses, e.g. in visit 1 , the TVC, EC, and GEC levels reached a peak of $5.5 \mathrm{log} \mathrm{CFU} / \mathrm{cm}^{2}, 0.8 \mathrm{log} \mathrm{CFU} / \mathrm{cm}^{2}$ and $2.0 \mathrm{log}$ $\mathrm{CFU} / \mathrm{cm}^{2}$, respectively compared to higher levels in visits 2 and 3, where the highest confirmed TVC levels were 8.1 and $6.4 \log \mathrm{CFU} / \mathrm{cm}^{2}$, respectively, EC levels were 1.4 and $1.2 \log \mathrm{CFU} / \mathrm{cm}^{2}$, respectively and E. coli levels were 2.2 and $2.1 \log \mathrm{CFU} / \mathrm{cm}^{2}$, respectively (Figure 1). Among the ten selected ante-mortem animal-based categories of importance for animal welfare, it was evident that the "manure on the body' correlated with microbial loads on carcasses. 'Insufficient space', 'lesions', 'injurious behaviour', 'feeding and drinking behaviour' and 'rest and sleep disruption' tended to correlate to microbial load levels to some extent; for instance, the higher scores given for those animal-based categories meant better process hygiene levels were measured, although no statistical correlation was found.

Other ante-mortem animal-based categories, 'mortality', 'disease signs', 'thermoregulation', and 'mutilation' were not correlated with levels of process hygiene. The post-mortem animal-based categories for fattening pigs with the poorest scores were 'gut pathologies', 'lung and respiratory tract pathologies' and 'liver pathologies'. The categories 'gut pathologies' and 'liver pathologies were associated with microbial loads on carcasses but not significantly, in terms that higher scores for those categories were associated better process hygiene levels, while 'lung and respiratory tract pathologies' did not correspond with microbial levels on carcasses. This finding also revealed that these three post-mortem categories should be regularly monitored at the slaughter line.

These findings highlight the importance of the animal-based category 'manure on the body' as important for both aspects - pig welfare in abattoir lairage, as well as for the level of process hygiene at slaughter. Improved status of pig welfare in abattoir lairage, associated with pre-slaughter assessment of animal-based categories, e.g. visual evaluation of animal cleanliness, can be a useful tool for maintaining control of the overall slaughter process hygiene and may be effective in reducing microbial contamination of carcasses (Delhalle et al., 2008).

\section{Conclusion}

The safety of the food chain is indirectly affected by welfare of animals farmed for food production, due to the close links between animal welfare, animal health and food borne diseases. Stress factors and poor welfare can lead to increased susceptibility to disease among animals and can intensify fecal shedding of food borne pathogens in the pre-slaughter phase: on-farm, in transport/livestock markets and in abattoir lairage. This could affect the process hygiene at slaughter/dressing and increase the public health risk for consumers. In this study, the European Food Safety Authority protocol intended for assessment of on-farm pig welfare was adapted to be used for assessment of welfare of fattening pigs in abattoir lairage. This approach is based on a group level assessment of animal-based categories. The results indicated that transportation time was not correlated with bacterial loads on carcasses (TVC, EC, GEC, Coliforms), while space allowance coupled with the lay-over time in lairage and ambient temperature tended to correlate with process hygiene; better space allowances, shorter lay-over times and higher 
temperatures were associated (but not statistically significantly) with lower microbial loads on carcasses. The ante-mortem animal-based categories for fattening pigs in abattoir lairage with the lowest scores were 'thermoregulation', 'manure on the body', 'insufficient space', 'injurious behavior' and 'lesions'. However, only manure on the body had any correlation or impact on process hygiene levels. Therefore, focus should be put, in particular, on 'manure on the body' category. The post-mortem animal-based categories for fattening pigs with the lowest scores were 'gut pathologies', 'lung and respiratory tract pathologies' and 'liver pathologies'. This finding revealed that these three categories should be regularly monitored on the slaughter line, as they could provide valuable feedback to the farm of origin, and reflect on the farm biosecurity level. Further and deeper research is needed to understand better the interface between animal welfare variables in abattoir lairage and slaughter process hygiene outcome.

Acknowledgment: We would like to thank to the meat industry "Yuhor", Jagodina, Serbia for its support in providing the full access to the production facilities needed to carry out this study.

Disclosure statement: No pontential conflict of interest was reported by authors.

\section{References}

Berends, B. R., VanKnapen, F., Snijders, J. M., \& Mossel, D. A. (1997). Identification and quantification of risk factors regarding Salmonella spp. on pork carcasses. International Journal of Food Microbiology, 36, 199-206.

Blagojevic, B., Antic, D., Ducic, M., \& Buncic, S. (2011). Ratio between carcass-and skin-microflora as an abattoir process hygiene indicator. Food Control, 22, 186-190.

Buncic, S., Steinhauserova, I., Smulders, F., Paulsen, P., Braun, P., Albert, T., \& Steinhauser, L. (2013). The Food Research, Safety and Training Network (FRST-NET) initiative, step one: Issues relevant for meat safety assurance at abattoir level. http://www.maso-international.cz/wp-content/uploads/2013/04/maso-international-2012-2-page-083-093.pdf (accessed on 9 September 2016).

Candiani, D., Salamano, G., Mellia, E., Doglione, L., Bruno, R., Toussaint, M. \& Gruys, E. (2008). A Combination of Behavioral and Physiological Indicators for Assessing Pig Welfare on the Farm. Journal of Applied Animal Welfare Science, 11, 1-13.

Del Campo, M., Brito, G., Montossi, F., de Lima, J. M. S., \& San Julián, R. (2014). Animal welfare and meat quality: The perspective of Uruguay, a "small" exporter country. Meat Science, 98, 470-476.

Delhalle, L., De Sadeleer, L., Bollaerts, K., Farnir, F., Saegerman, C., Korsak, N., Dewulf, J., De Zutter, L., \& Daube, G. (2008). Risk factors for Salmonella and hygiene indicators in the 10 largest Belgian pig slaughterhouses. Journal of Food Protection, 71, 1320-1329.

Dokmanovic, M., Velarde, A., Tomovic, V., Glamoclija, N., Markovic, R., Janjic, J., \& Baltic, M. (2014). The effects of lairage time and handling procedure prior to slaughter on stress and meat quality parameters in pigs. Meat Science, 98, 220-226.

EC. (2005). Commission Regulation (EC) No 2073/2005 of 15 November 2005 on microbiological criteria for foodstuffs.

EC. (2009). Council Regulation 1099/2009 on the protection of animals at the time of killing.
EFSA. (2012). Scientific Opinion on the use of animal-based measures to assess welfare in pigs. EFSA Journal, 10, 2512.

EFSA. (2013a). Scientific Opinion on monitoring procedures at slaughterhouses for pigs.

EFSA Journal, 11, 3523.

EFSA. (2013b). Scientific Opinion on monitoring procedures at slaughterhouses for bovines.

EFSA Journal, 11, 3460.

Faucitano, L. (2010). Effects of lairage and slaughter conditions on animal welfare and pork quality. Canadian Journal of Animal Science, 90, 461-469.

FAWC. (2013). Space allowances in slaughterhouse lairage (Farm Animal Welfare Committee. http://www.defra.gov. uk/fawc (accessed on 2 September 2016).

Ferguson, D. M., Bruce, H. L., Thompson, J. M., Egan, A. F., Perry, D., \& Shorthose, W. R. (2001). Factors affecting beef palatability - Farmgate to chilled carcass. Australian Journal of Experimental Agriculture, 41, 879-892.

Fraqueza, M. J., Roseiro, L. C., Almeida, J., Matias, E., Santos, C., \& Randall, J. M. (1998). Effects of lairage temperature and holding time on pig behaviour and on carcass and meat quality. Applied Animal Behaviour Science, 60, 317-330.

Geverink, N. A., Engel, B., Lambooij, E., \& Wiegant, V. M. (1996). Observations on behavior and skin damage of slaughter pigs and treatment during lairage. Applied Animal Behaviour Science, 50, 1-13.

Gill, C. O., Dussault, F., Holley, R. A., Houde, A., Jones, T., Rheault, N., Rosales, A., \& Quessy, S. (2000). Evaluation of the hygienic performances of the processes for cleaning, dressing and cooling pig carcasses at eight packing plants. International Journal of Food Microbiology, $58,65-72$.

Gispert, M., Faucitano, L., Oliver, M. A., Guardia, M. D., Coli, C., Siggens, K., Harvey, K., \& Diestre, A. (2000). A survey of pre-slaughter conditions, halothane gene frequency, and carcass and meat quality in five Spanish pig commercial abattoirs. Meat Science, 55, 97-106. 
Grandin, T. (1996). Animal Welfare in Slaughter Plants. 29th Annual Conference of American Association of Bovine Practitioners. Proceedings, 22-26. http://www.grandin. com/welfare/general.session.html (accessed on 29 August 2016).

Guàrdia, M. D., Estany, J., Balasch, S., Oliver, M. A., Gispert, M., \& Diestre, A. (2009). Risk assessment of skin damage due to pre-slaughter conditions and RYR1 gene in pigs. Meat Science, 81, 745-751.

Guàrdia, M. D., Estany, J., Balasch, S., Oliver, M. A., Gispert, M., \& Diestre, A. (2010). Risk assessment of DFD meat due to pre-slaughter conditions in pigs. Meat Science, 70, 709-716.

Horchner, P. M. \& Pointon, A. M. (2011). HACCP-based program for on-farm food safety for pig production in Australia. Food Control, 22, 1674-1688.

ISO 16649-1. (2001). Microbiology of food and animal feeding stuffs - Horizontal method for the enumeration of beta-glucuronidase-positive Escherichia coli - Part 1: Colony-count technique at 44 degrees $\mathrm{C}$ using membranes and 5-bromo-4-chloro-3-indolyl beta-D-glucuronide.

ISO 6579. (2002). Microbiology of food and animal feeding stuffs - Horizontal method for the detection of Salmonella spp.

ISO 4833. (2003). Microbiology of food and animal feeding stuffs - Horizontal method for the enumeration of microorganisms - Colony-count technique at 30 degrees $\mathrm{C}$.

ISO 21528-2. (2004). Microbiology of food and animal feeding stuffs - Horizontal methods for the detection and enumeration of Enterobacteriaceae - Part 2: Colony-count method.

ISO 4832. (2006). Microbiology of food and animal feeding stuffs - Horizontal method for the enumeration of coliforms - Colony-count technique.

ISO 17604. (2015). Microbiology of the food chain - Carcass sampling for microbiological analysis.

Nastasijevic, I., Tomasevic, I., Smigic, N., Milicevic, D., Petrovic, Z., \& Djekic, I. (2016). Hygiene assessment of Serbian meat establishments using different scoring systems. Food Control, 62, 193-200.

Petruzzelli, A., Osimani, A., Pasquini, M., Clementi, F., Vetrano, V., Paolini, F., Foglini, M., Micci, E., Paoloni, A., \& Tonucci, F. (2016). Trends in the microbial contamination of bovine, ovine and swine carcasses in three small-scale abattoirs in central Italy: A four-year monitoring. Meat Science, 111, 53-59.

Rostagno, M. H. (2009). Can stress in farm animals increase food safety risk? Foodborne Pathogens and Disease, 6(7), 767-776.

RSPCA (2014). RSCPA welfare standards for pigs. http://science.rspca.org.uk/sciencegroup/farmanimals/standards/ pigs (accessed on 29 August 2016).

Spoolder, H. A. M., Edwards, S. A., \& Corning, S. (2000). Legislative methods for specifying stocking density and consequences for the welfare of finishing pigs. Livestock Production Science, 64, 167-173.

Sutherland, M. A., Bryer, P. J., Davis, B. L. \& McGlone, J. J. (2010). A Multidisciplinary Approach to Assess the Welfare of Weaned Pigs During Transport at Three Space Allowances. Journal of Applied Animal Welfare Science, 13, 237-249.

USDA FSIS. (1996). Guidelines for Escherichia coli Testing for Process Control Verification in Cattle and Swine Slaughter Establishments. http://www.fsis.usda.gov/wps/ wcm/connect/cebac8d0-954b-4cc2-abcf-205ad4f4ddcd/Guideline for Ecoli Testing Cattle Swine Estab. pdf?MOD=AJPERES (accessed on 7 September 2016).

USDA FSIS. (2013). FSIS Compliance Guide for a Systematic Approach to the Humane Handling of Livestock. http://www.fsis.usda.gov/wps/wcm/connect/da6cb63d5818-4999-84f1-72e6dabb9501/Comp-Guide-Systematic-Approach-Humane-Handling-Livestock. pdf?MOD=AJPERES (accessed on 7 September 2016).

van Erp-van der Kooij, E., Kuijpers, A. H., Schrama, J. W., van Eerden-burg, F. J. C. M., Schouten, W. G. P., \& Tielen, M. J. M. (2002). Can we predict behaviour in pigs? Searching for consistency in behaviour over time and across situations. Applied Animal Behaviour Science, 75, 293-305.

Weeks, C. A. (2008). A review of welfare in cattle, sheep and pig lairages, with emphasis on stocking rates, ventilation and noise. Animal Welfare, 17, 275-284.

Yousuf, M. I. (2007). Using experts' opinions through delphi technique. Practical Assessment, Research and Evaluation, 12, 8.

Zweifel, C., Fischer, R., \& Stephan, R. (2008). Microbiological contamination of pig and cattle carcasses in different small-scale Swiss abattoirs. Meat Science, 78, 225-231. 